Journal of Educational Method and Technology Vol. 2 No. 1, April 2019

P-ISSN 2622-8459 E-ISSN 2622-8467

http://ejournal.unima.ac.id/index.php/jemtec

\title{
The Effect Of The Use Of Computer Helpful Learning Media On The Results Of Learning Themes Of Events In Living Class V SD
}

\author{
J M Sumilat ${ }^{1}$ \\ ${ }^{1}$ Universitas Negeri Manado, Indonesia \\ corresponding author: ${ }^{1}$ julianasumilat@unima.ac.id
}

\begin{abstract}
Abstrak. The purpose of this research is to know the effect of the use of computer assisted learning media on the learning outcomes of event themes in the lives of Class V elementary school students. This study uses an experimental method with bound variables (Y) is the result of learning the theme of events in the lives of students of class V SD, and the independent variable $(\mathrm{X})$ is the use of computer-assisted learning media. The research was conducted at SD Negeri 2 Tataaran in October 2018. Learning outcomes data were analyzed using the t test, but previously tested normality and homogeneity as a prerequisite test. The results of this study conclude that there is an influence of the use of computer assisted learning media on learning outcomes of students in Class V SD which causes differences in achievement of learning outcomes, where the results of the theme "events in life" groups of students who use computer assisted learning media are higher than groups of students who do not use computer-assisted learning media.
\end{abstract}

\section{Introduction}

The progress of a nation is determined by several factors including the quality of human resources. The quality of human resources can be established in formal education institutions. In Indonesia, primary school institutions are formal education institutions, therefore the quality of education in primary schools is the basis for the formation of the quality of human resources. The quality of education in elementary schools can be seen from the results of learning every output, in this case the learning outcomes of the students themselves.

Learning outcomes of students are determined by several factors, namely internal factors (physical, psychological, fatigue) and external factors (family, school, and society), where in external factors more specifically the school include curriculum, teaching methods, learning media, teacher relations and students [1]. The selection of the right learning media by the teacher can determine the achievement of learning outcomes, because learning media has several functions including as a means of making effective learning, accelerating the learning process, and improving the quality of learning and interpreting abstinent learning so as to avoid verbalism [2]. Sutjiono explained the need for the use of learning media in learning in 
elementary schools because it can help teachers explain things that have never been seen even experienced by students in real life so that learning can be effective and efficient [3]. The use of learning media can have an influence on student learning outcomes such as the results of Esti Wahyuni's research, namely there are differences in the average score of learning in learning that utilizes multi-media with those that do not use multi-media, and provide high effects to form achievement motivation the effect of being in the acquisition of learning outcomes [4].

In elementary school learning class $\mathrm{V}$ with the theme of events in life many facts can be taught so students can construct their knowledge. But in presenting the facts of events in everyday life can be time consuming, therefore it is very necessary for learning media that can help present material comprehensively with minimal use of time. One of the learning media that can present it is a computer-assisted learning media. Starting from the description above, the researcher felt interested in conducting research with the title "The Effect of Using Computer Assisted Learning Media on Learning Outcomes of Event Themes in the Life of V SD Class Students".

The rapid development of technology is a solution that can be utilized to solve the problems of the quality of education that have occurred so far. One example of problems that often occur in the learning process that can determine the level of learning is verbalism where there is an understanding of receiving learning messages. But so far there are still a number of elementary school teachers in the sub-district of Tondano south who still doubt the use of computer-assisted learning media due to several reasons including being less proficient in technology, or costing quite a lot of money. Therefore researchers feel the importance of conducting this study to address the benefits of using computer-assisted learning media as an effort to increase the interest and motivation of these elementary school teachers in the use of computerassisted learning media as an effort to create an effective and efficient learning process so as to make learning outcomes achievable the maximum and improve the quality of education itself. The purpose of this research is to know the effect of the use of computer assisted learning media on the learning outcomes of event themes in the lives of Class V elementary school students. The problem statement in this study is whether there are differences in the results of learning the theme of events in life between groups of students who use computer-assisted learning media with groups of students who do not use computer-assisted learning media?

\section{Methods}

This study uses an experimental method with dependent variables ( $Y$ ) is the learning outcome of learning the theme "events in the lives" of students of class V $\mathrm{SD}$, and the independent variable $(\mathrm{X})$ is the use of computer-assisted learning media. This research was conducted at SD Negeri 2 Tataaran in October 2018. Learning outcomes data were analyzed using the t test, but previously tested for normality and homogeneity as a prerequisite test. 


\section{Results and Discussions \\ Results}

Learning outcomes data in this study were processed with the help of SPSS computer program. Descriptives of research data are presented in table 1.

Tabel 1. Descriptives of research data

\begin{tabular}{|c|c|c|c|c|c|}
\hline \multirow{2}{*}{ Nilai } & \multicolumn{3}{|c|}{ Kelompok } & \multirow{2}{*}{$\begin{array}{r}\text { Statistic } \\
3.1983\end{array}$} & \multirow{2}{*}{$\begin{array}{r}\text { Std. Error } \\
.02133\end{array}$} \\
\hline & 1 & Mean & & & \\
\hline \multirow{27}{*}{ Nilai } & & 95\% Confidence & Lower & 21547 & \\
\hline & & Interval for Mean & Bound & 3.1542 & \\
\hline & & & $\begin{array}{l}\text { Upper } \\
\text { Bound }\end{array}$ & 3.2425 & \\
\hline & & $5 \%$ Trimmed Mean & & 3.1977 & \\
\hline & & Median & & 3.1850 & \\
\hline & & Variance & & .011 & \\
\hline & & Std. Deviation & & .10449 & \\
\hline & & Minimum & & 2.93 & \\
\hline & & Maximum & & 3.47 & \\
\hline & & Range & & .54 & \\
\hline & & Interquartile Range & & .08 & \\
\hline & & Skewness & & .296 & .472 \\
\hline & & Kurtosis & & 2.410 & .918 \\
\hline & 2 & Mean & & 2.9917 & .01741 \\
\hline & & 95\% Confidence & Lower & 29556 & \\
\hline & & Interval for Mean & Bound & & \\
\hline & & & $\begin{array}{l}\text { Upper } \\
\text { Bound }\end{array}$ & 3.0278 & \\
\hline & & $5 \%$ Trimmed Mean & & 2.9918 & \\
\hline & & Median & & 2.9900 & \\
\hline & & Variance & & .007 & \\
\hline & & Std. Deviation & & .08348 & \\
\hline & & Minimum & & 2.82 & \\
\hline & & Maximum & & 3.16 & \\
\hline & & Range & & .34 & \\
\hline & & Interquartile Range & & .14 & \\
\hline & & Skewness & & .144 & .481 \\
\hline & & Kurtosis & & -.037 & .935 \\
\hline
\end{tabular}

The results of the research in table 1 show that in the experimental class the learning outcomes of sub-theme 1 had an average of 3,208 and a standard deviation of 0,204 ; sub-theme 2 has an average of 3,207 and a standard deviation of 0,153 ; sub- theme 3 has an average of 3.180 and a standard deviation of 0.145 . While in the learning outcomes control class sub-theme 1 has an average of 2.960 and a standard 
deviation of 0.189 ; sub-theme 2 has an average of 3.037 and a standard deviation of 0.098; sub-theme 3 has an average of 2.982 and a standard deviation of 0.096 .

Furthermore, to more clearly see the difference in treatment effects on each class used the $t$ test. but before conducting the $t$ test, the prerequisite test is carried out first, namely the normality test and homogeneity test. The normality test is conducted on the learning outcomes of sub-themes 1, sub-themes 2 and sub-themes 3 and can be seen in table 2 below.

Table 2. Results of the Normality Test of the Third Sub-theme

\begin{tabular}{|c|c|c|c|c|c|c|c|}
\hline & \multirow[b]{2}{*}{ Group } & \multicolumn{3}{|c|}{ Kolmogorov-Smirnova } & \multicolumn{3}{|c|}{ Shapiro-Wilk } \\
\hline & & Statistic & $\mathrm{df}$ & Sig. & Statistic & df & Sig. \\
\hline \multirow{2}{*}{$\begin{array}{l}\text { value of } \\
\text { sub- } \\
\text { thema } 1\end{array}$} & 1 & .163 & 24 & .101 & .940 & 24 & .165 \\
\hline & 2 & .168 & 23 & .090 & .909 & 23 & .039 \\
\hline \multirow{2}{*}{$\begin{array}{l}\text { value of } \\
\text { sub- } \\
\text { thema } 2\end{array}$} & 1 & .165 & 24 & .091 & .960 & 24 & .448 \\
\hline & 2 & .141 & 23 & $.200^{*}$ & .962 & 23 & .505 \\
\hline \multirow{2}{*}{$\begin{array}{l}\text { value of } \\
\text { sub- } \\
\text { thema } 3\end{array}$} & 1 & .107 & 24 & $.200^{*}$ & .970 & 24 & .664 \\
\hline & 2 & .082 & 23 & $.200^{*}$ & .978 & 23 & .873 \\
\hline
\end{tabular}

a. Lilliefors Significance Correction

The results of the normality of the learning outcomes data of the 3 sub-themes presented in table 2 of the Kolmogrov-Smirnov column which are equivalent to Liliforce testing indicate that all the value values are $>0.05$. This means that all data groups are normal. The prerequisite test is continued with the homogeneity test. The homogeneity test results from the learning outcomes of the 3 sub-themes are presented in the following table 3 . In table 3, the learning outcomes of the 3 subthemes show that the significance value is $>0.05$, this means that the learning outcomes of the 3 sub-themes are homogeneous or have the same variants.

Table 3. Homogeneity Test of the 3rd Learning Outcome Sub-Theme

\begin{tabular}{ccccc}
\hline Sub Thema & $\begin{array}{c}\text { Levene } \\
\text { Statistic }\end{array}$ & df1 & df2 & Significance \\
\hline 1 & 0,077 & 1 & 45 & 0,783 \\
\hline 2 & 3,309 & 1 & 45 & 0,076 \\
\hline 3 & 2,120 & 1 & 45 & 0,152 \\
\hline
\end{tabular}

After testing the normality and homogeneity, it has been shown that the learning outcomes data are normal and have the same or homogeneous variants. Thus the prerequisite test has been fulfilled and hypothesis testing is continued with the $t$ test. The results of the $t$ test for sub-theme 1 learning outcomes data are presented in table 4. 
Table 4. Hypothesis testing of learning outcomes data

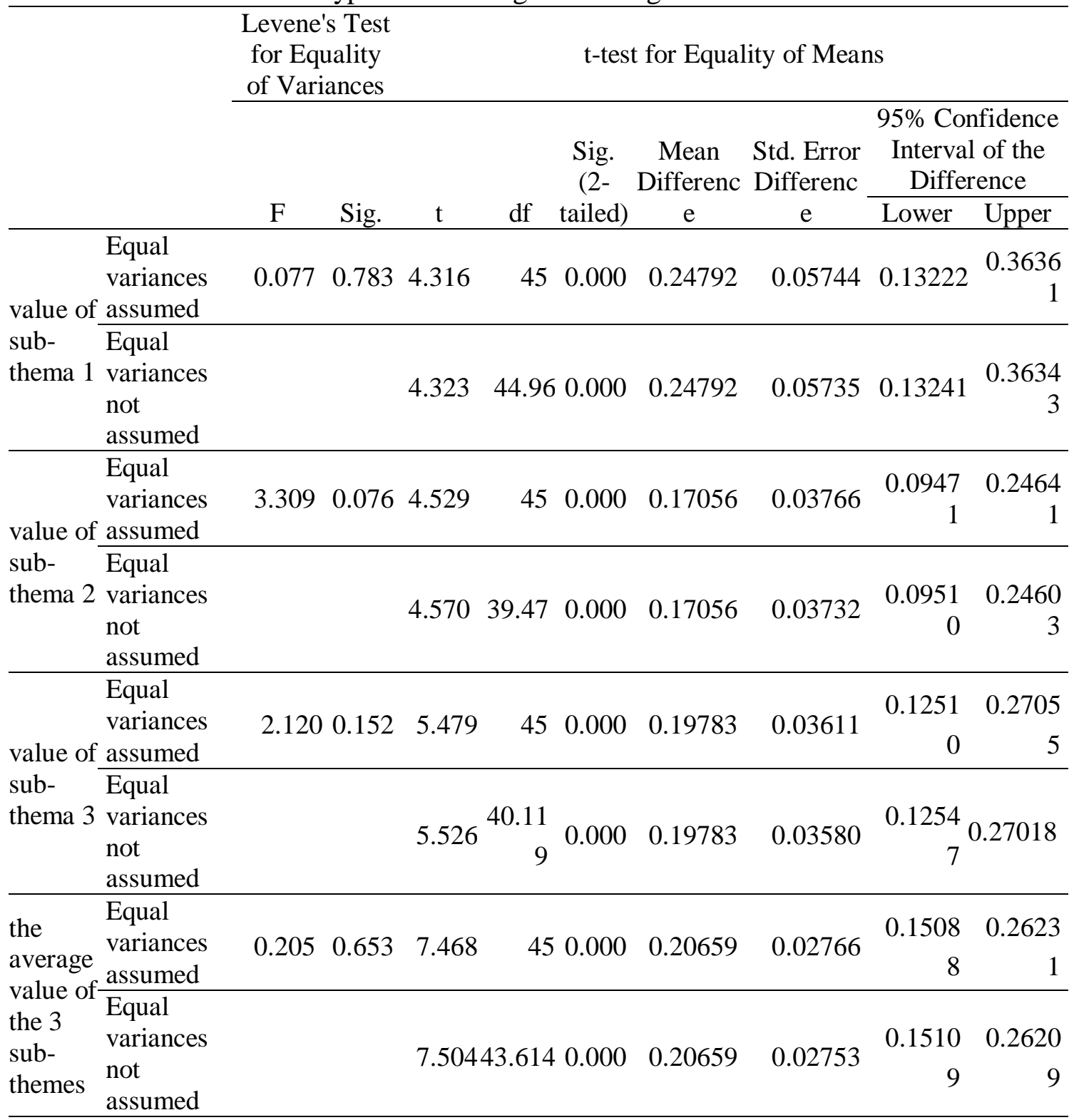

The value of the $t$ test on testing the results of the sub-themes 1 is $t$ count $=$ 4.316>t table $=2,000$. This means that there are differences in the learning outcomes of sub-themes 1 between the experimental and control groups, where the results of learning sub-themes 1 group of students using computer-assisted learning media is higher than the group of students who do not use computer-assisted learning media. The value of the $t$ test for testing the results of the sub-themes 2 is $t=4.529>t$ table $=2,000$. This means that there are differences in the learning outcomes of subthemes 2 between the experimental group and the control group, where the results of learning than the group of students who do not use computer-assisted learning media. The value of the $t$ test on the testing of the results of the sub-themes 3 is $t$ count $=$ $5.479>t$ table $=2,000$. This means that there are differences in the learning outcomes 
of sub-themes 3 between the experimental group and the control group, where the results of learning sub-themes 3 groups of students using computer-assisted learning media are higher than the group of students who do not use computer-assisted learning media.

The value of the $t$ test on the testing of the average learning outcomes of the 3 sub-themes of the theme of events in life is thitung $=7.468>t$ table $=2,000$. This means that there are differences in the average learning outcomes of the 3 sub themes on the theme of events in life between the experimental group and the control group, or there is the influence of the use of computer-assisted learning media on the learning outcomes of event themes in the life of fifth grade students, where the influence of media use computer assisted learning causes differences in learning outcomes between groups and the differences shown are the results of learning the theme of "events in life" groups of students who use computer-assisted learning media higher than groups of students who do not use computer-assisted learning media.

Furthermore, to find out more clearly the influence of the use of computerassisted media which caused differences in the results of learning the theme of events in the lives of fifth grade elementary school students, the gain data were analyzed from the two groups. Data gain used in this test is a change that occurs between the learning outcomes of sub-themes 1 and sub-theme 3 .

Table 5. Hypothesis Test Data on Learning Outcomes Sub Theme 1 and Sub Theme 3

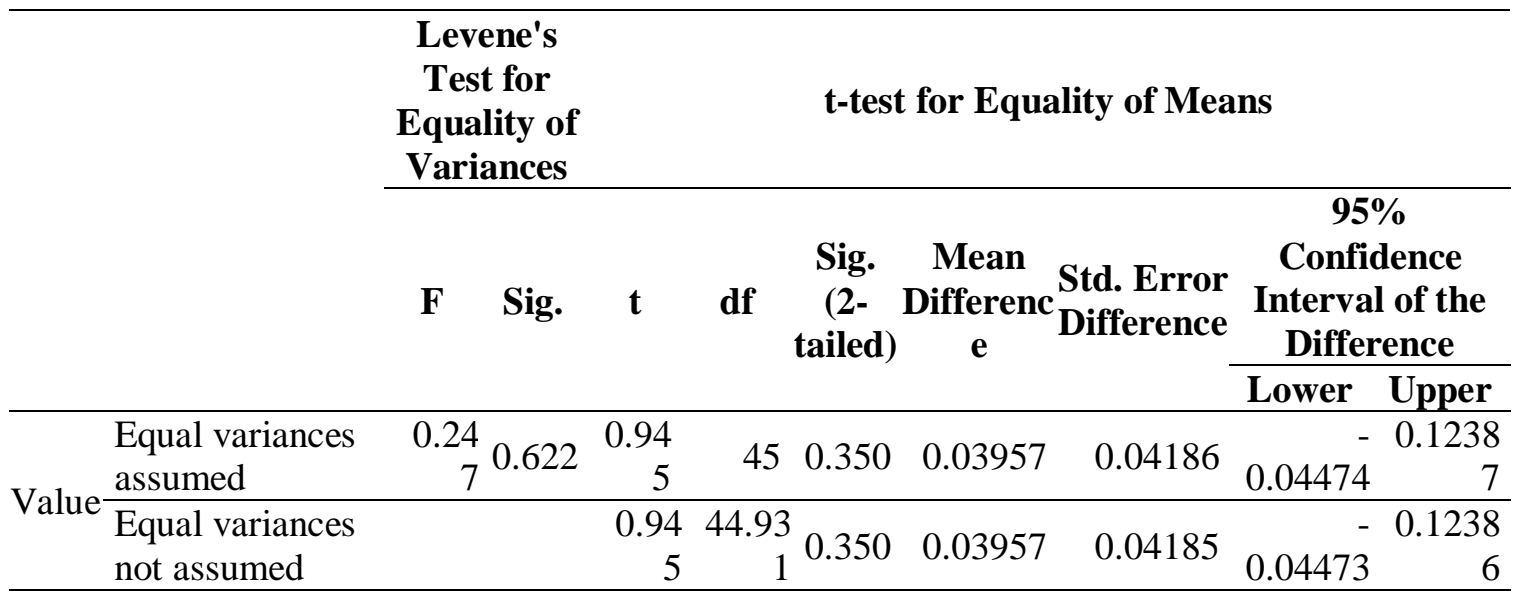

The results of the independent test $t$ from the data gain sub themes 1 and 3 in table 5 show the results of $t$ test is $t$ count $=0.945>t$ table $=2,000$, this means that there is an influence of the use of computer-assisted learning media that causes differences in learning outcomes between the two groups, where the learning themes are "events in life" groups of students who use assisted learning media computer is higher than the group of students who do not use computer-assisted learning media.

Based on the description above, it can be concluded that the findings of this study show that the results of learning the theme of "events in life" groups of 
students who use computer-assisted learning media are higher than groups of students who do not use computer-assisted learning media.

\section{Discusion}

Thematic learning is learning that demands the professionalism of a teacher, because in thematic learning the teacher must be clever in planning learning and packaging it so that the achievement of learning messages that contain various elements of the subject can motivate students so that students achieve optimal learning outcomes. this is as stated by Tuerah that learning management which is one of the main tasks of the teacher influences its performance [5].

Learning the themes of "events in life" for each sub-theme requires the teacher to make students connect one learning to another. On the other hand, learning the theme of "events in life" requires the child to understand the contents of the reading text about the water cycle and its impact on events on earth, and to recount both in oral and written language; and understanding social cultural and economic diversity in the participation of students in positive activities that help communities around the home and school environment; and connected with art in this case drawing or making works. In the process of delivering learning messages which are described above, it requires the teacher to create learning media that are able to convey learning messages while being able to save learning time. The findings of this study have proven that the use of computer-assisted learning media in thematic learning the theme of "events in life" is able to provide optimal learning outcomes, where learning outcomes using computer-based media is higher than student learning outcomes that do not use computer-assisted learning media. The findings of this study are in line with the results of research from Aloraini which concluded that there were statistically significant differences between groups using computer or multimedia presentation programs and groups using traditional methods with dialogue and discussion techniques [6]. In addition, the findings of this study are also in line with the research findings of Al-Hariri and Hattami, who concluded that the use of technology can result in increased academic achievement or relatively more learning outcomes than not using technology in learning [7].

In the learning process understanding the water cycle and its benefits will be more quickly understood by students if using computer-assisted learning media. Because with the help of computer-assisted learning media the water cycle can be visualized so that children with direct vision experience can retell the recycling process or water cycle and the benefits of life in the home environment. Thus the required Indonesian language competence is to understand the readings or illustrations that are available to be retold and to become knowledgeable for community life. The benefits of using computer assisted learning media found in this study are in line with the findings of Lai and Kritsonis' research which prove that the use of computer technology has a positive effect on the level of student achievement in learning English as a second language [8]. However, the use of computer-assisted learning media sometimes has limitations, therefore we need to understand the learning media used in learning as stated by Cairncross and Mannion that if we want 
to design effective computer-assisted learning media, the design process must be centered or student-oriented and must be based on the principles of interaction between humans and computers in general and educational theory [9].

\section{Conclusions}

Based on the results of the research and discussion, it can be concluded that there is the influence of the use of computer-assisted learning media on student learning outcomes that cause differences in achievement of learning outcomes, where the learning outcomes of theme "events in life" groups of students using computerassisted learning media are higher than student groups who do not use computerassisted learning media

\section{References}

[1] Slameto. (2010). Belajar dan Faktor- Faktor yang Mempengaruhinya. Jakarta: Pustaka Indonesia

[2] Nurseto, T. (2011). Membuat media pembelajaran yang menarik. Jurnal Ekonomi dan Pendidikan, 8(1).

[3] Sutjiono, T. W. A. (2005). Pendayagunaan media pembelajaran. Jurnal Pendidikan Penabur, 4(4), 76-84.

[4] Wahyuni, E. (2011). Pengaruh pemanfaatan multimedia dalam pembelajaran fisika terhadap pemerolehan belajar. Jurnal Visi Ilmu Pendidikan, 7(1).

[5] Tuerah, R. M. (2017, September). Analysis of Teacher Performance on Learning Managment in Primary School. In 9th International Conference for Science Educators and Teachers (ICSET 2017). Atlantis Press.

[6] Aloraini, S. (2012). The impact of using multimedia on students' academic achievement in the College of Education at King Saud University. Journal of King Saud University-Languages and Translation, 24(2), 75-82.

[7] Al-Hariri, M. T., \& Al-Hattami, A. A. (2017). Impact of students' use of technology on their learning achievements in physiology courses at the University of Dammam. Journal of Taibah University Medical Sciences, 12(1), 82-85.

[8] Lai, C. C., \& Kritsonis, W. A. (2006). The advantages and disadvantages of computer technology in second language acquisition. Online Submission, 3(1).

[9] Cairncross, S., \& Mannion, M. (2001). Interactive multimedia and learning: Realizing the benefits. Innovations in education and teaching international, 38(2) 